\title{
"I really don't wanna think about what's going to happen to me!": a case study of psychological health and safety at an isolated high Arctic Research Station
}

\author{
Anna G. M. Temp ${ }^{1,2}$ (D) Billy Lee ${ }^{1} \cdot$ Thomas Bak $^{1}$ (D) \\ Received: 31 January 2019 / Revised: 28 October 2019 / Accepted: 25 November 2019 / Published online: 16 March 2020 \\ (C) The Author(s) 2020
}

\begin{abstract}
Psychological problems over the course of isolated missions in extreme environments are common, even with modern screening techniques. Occasionally, these problems warrant evacuation of the afflicted individual but no in-depth insight into such a case has been given in modern times, until now. A 21-year-old man - Albert - developed severe psychological distress over the course of a winter expedition to the Polish Polar Station, Svalbard. We collected data on his mental health and his mood using the Symptom Checklist 90Revised and the Profile of Mood States, and we assessed his cognitive functions with the Sustained Attention to Response Task and the Test of Everyday Attention. Phenomenological interviews gave him room to relate his experience. The data collection occurred repeatedly during the mission, until his evacuation. Albert struggled to derive joy from his work at the station. He missed his loved ones at home, and he felt he was cognitively declining due to intellectual deprival. His attempt at combing his life at home and his life at the station led to him feeling increasingly depressed. Crawfordian case analysis suggests that he felt more depressed than other team members at the station, and men of equal age and education in their home environment $(p<001)$. We attempted an intervention using emotional freedom techniques (EFT) to help improve his symptoms. It was moderately successful. Albert's evacuation was medically warranted. The intervention temporarily alleviated his depressive symptoms. More such case studies should be conducted wherever possible.
\end{abstract}

Keywords Isolated and confined environments $\cdot$ Extreme environments $\cdot$ Winter-over syndrome $\cdot$ Polar psychology $\cdot$ Emotional freedom techniques

\section{Introduction}

Extreme environments feature three core characteristics: a hazardous physical surrounding, a demanding mission goal, and limited communications with loved ones at home (Blair 1991, p. 57). Isolated research stations in both polar regions Antarctica and the Arctic - qualify as extreme environments:

Anna G. M. Temp

agm.temp@ed-alumni.net

Billy Lee

b.lee@ed.ac.uk

Thomas Bak

thomas.bak@ed.ac.uk

1 School of Philosophy, Psychology and Languages, The University of Edinburgh, 7 George Square, EH8 9JZ Edinburgh, Scotland

2 The Institute of Geophysics, Polish Academy of Sciences, Księcia Janusza 64, 01-452 Warsaw, Poland
Antarctica is the highest, coldest, windiest, and driest of all continents (Palinkas 1990) where evacuation is nigh impossible during the winter months (Grant et al. 2007), and while the High Arctic climate is milder (Steel et al. 1997), there are dangerous predators such as polar bears which contribute to the environment's hostility (Norwegian Polar Institute 2005). This results in fire arms - which are banned in Antarctica - being a necessity at Arctic stations. The key stressors at such research stations include minimal privacy, boredom, sexual and emotional deprivation, artificial possibilities for social interaction, and reduced opportunity to escape or avoid interpersonal conflicts (Palinkas 1990). In Antarctica, the crew members' isolation from home and confinement to the station have continuously been shown to contribute to mental health issues in humans (see Palinkas and Suedfeld 2008 for a review). Even a single crew member's mental health issues can pose profound safety issues for the entire crew because a lack of vigilance may result in damage to the station buildings (Levesque 1991, p. 16), or, as occasionally reported in the media, violent outbursts (for a recent example, see Weisberger 2018). There is a plethora of research describing such mental health 
fluctuations in Antarctic crews, spanning all decades since the International Polar Year (IPY, 1957-58), for examples see Pope and Rogers (1968), Strange and Klein (1973), Bell and Garthwaite (1987), Palinkas et al. (1995); and Palinkas et al. (2004, 2010). Psychological research into an Arctic crew has suggested that there may be similar group fluctuations over the course of a one-year mission (Temp et al. 2017).

However, all of these reports describe the crews as an entire group, with participants who experience stronger psychological symptoms often being excluded from the data analysis. Three of Bell and Garthwaite's (1987) participants were evacuated on psychiatric grounds - one had not recovered even a year later. In 2004, Palinkas, Glogower, Dembert, Hansen and Smullen noted that at the end of an Antarctic mission, approximately $5 \%$ of participants satisfied criteria for various personality disorders that were not present at baseline. More recently, Pattarini et al. (2016) observed that the only two winter evacuations of 2013/14 at the Antarctic McMurdo Station were due to psychiatric complications. This suggests that psychiatric complications over the course of polar night pose a threat to the afflicted crew members and by extension their coworkers, but no in-depth analysis of these crew members has ever been published or discussed. This is a wide gap in the current polar psychology literature, considering that case studies of what used to be called polar depression during the Heroic Age of Antarctic Exploration (1897-1917) is where modern polar psychology originated (Palinkas 2003). The only detailed accounts of major inter- and intrapersonal issues based on psychiatric complications come to us from the diaries of the explorers of the Heroic Age. During the British Antarctic Expedition (1907-09), Douglas Mawson and Alistair Mackay's diaries both outline how their leader, Professor Edgeworth David, became so unstable that they had to force him to name Mawson leader instead (see Roberts 2014, p. 73ff). In the official version of the events Ernest Shackleton's The Heart of the Antarctic -, the professor claims to have made this choice voluntarily which shows that there is a considerable stigma associated with psychiatric issues during a polar mission. Several years later, on Mawson's Australasian Antarctic Expedition (1911-14), another crew member, Sidney Jeffryes, developed aggravated paranoia, suspiciousness and aggression towards his fellow crew members. Jeffryes' behaviour became such a threat to the crew's physical safety and mental well-being that they placed him under constant surveillance (see Roberts 2014 p. 260ff). Recently, a more empathetic view of Jeffryes has been presented (Norris et al. 2018) but these two historic examples demonstrate the necessity to investigate and analyse case studies of psychiatric evacuation from polar stations in current times. Even the recently published examples of good safety practices for Arctic station managers (INTERACT 2014 p. 104) do not take psychological well-being and safety into consideration.
This paper presents the first modern case study of psychiatric complications over the course of polar night. As such, it explores the thoughts, feelings, and behaviours of a 21-yearold man named Albert who joined a mission to the Polish Polar Station at Hornsund, Svalbard. We also propose a potential approach to alleviating emotional distress over the course of polar night. All relevant details have undergone full anonymisation to grant Albert full confidentiality.

\section{Methodology}

\section{Design}

The original design of this study was a group-based, withinsubjects analysis of the whole crew's well-being, cognitive state and personal experiences over the course of a year, see Temp et al. (2018) for a detailed methodological account and Temp et al. (2017) for the group-based emotional outcomes. The five measurements taken over the year were "After Arrival [at the station]" in July, "Equinox" (September), "Winter Isolation" (January), "Spring" (April) and "Before Departure" (June). Albert participated in the first three of these, two of which involved phenomenological interviews: September and January. Over the course of this year, it became clear that Albert was more severely affected by his mission than the rest of his crew, and that he would require evacuation. Following this, we decided to remove his data from the group analysis because it was an outlier which made it look as if the overall group reported much more severe issues than they actually did. We then decided which of the quantitative measures (see below) should be analysed in detail based on his lived experience at the station in January, as suggested by Creswell and Plano Clark (2011), p. 71).

\section{Participants}

Albert was a 21-year-old Polish man with a background in physics. He left his parents, grandfather and partner behind to take on the position of the expedition's geophysicist. He reported no prior depression or thyroid issues at baseline. His quantitative results will be compared to two groups: firstly, the other station members ("Explorers"), and secondly, a group of men of his own age and education status who live in their home environment rather than at an isolated station ("Controls"). There were nine Explorers, three of them women, see Table 1.

There were six Controls, none of whom reported prior thyroid issues or depression. They were British $(n=2)$, Malaysian $(n=1)$, Singaporean $(n=1)$ and Greek $(n=1)$; one did not indicate his nationality. Their demographic background can be found in Table 2 . 
Table 1 The demographic background (Mean (SD)) of Albert's colleagues at the station (the "explorers")

\begin{tabular}{ll}
\hline Demographic variable & Explorers \\
\hline Age & $33.10(10.80)$ \\
Sex & 3 women, 6 men \\
Years of Education & $11.9(1.85)$ \\
Marital Status & \\
$\quad$ Single & 4 \\
Unmarried relationship & 4 \\
Married & 1 \\
Divorced & 0 \\
Thyroid Status & \\
Hypothyroidism & 1 \\
Hyperthyroidism & 0 \\
Healthy thyroid & 9 \\
Depression Status & \\
Past depression & 1 \\
Current depression & 0 \\
No depression & 9 \\
\hline
\end{tabular}

Attempts were made to recruit from Edinburgh University's Polish Society which has many suitably -aged and -educated student members, but none volunteered. So Albert's Controls were recruited from the general student body with the requirement that they must not be natives to Edinburgh or the UK. The idea here was to compare Albert to peers who were also separated from their families but not isolated at a research station.

\section{Measures}

There were three approaches to this study: phenomenological interviewing to give Albert room to relate his experience, quantitative questionnaires measuring mood and mental health, and cognitive testing to investigate memory and attention.

Interviews We employed interpretative phenomenological analysis (IPA) to facilitate the interview and understand Albert's experience. In September, we asked "What is extreme about this environment?" and in January, we asked "What has

Table 2 The control's demographic background

\begin{tabular}{ll}
\hline Demographic variable & Mean (SD) \\
\hline Age & $24.33(1.03)$ \\
Education & $16.00(2.52)$ \\
Marital Status & \\
$\quad$ Single & 3 \\
$\quad$ Unmarried relationship & 3 \\
\hline
\end{tabular}

changed?". Phenomenology concentrates on "persons-in-context" (Larkin et al. 2006, p. 108. During the interview, the participant is given room to make sense of all their experiences; the researcher aims to put themselves and their ideas about the subject that being talked about aside in order to find out what is meaningful to the participant. The goal is to understand how a certain phenomenon has been understood by this participant, and what this phenomenon means for this person, in this context (Larkin et al. 2006). Once the interview has finished, the researcher explores, describes and interprets the participants' account. All participants were offered a choice of English, or Polish with an interpreter. Albert chose to be interviewed in English.

Symptom Checklist 90 Revised (SCL-90-R) This comprehensive mental health assessment yields insight into the participants' symptomatology with regard to somatization, obsessive-compulsive, interpersonal sensitivity, depression, anxiety, hostility, phobic anxiety, paranoid ideation and psychoticism.

Profile of Mood States (POMS) This questionnaire has yielded mood fluctuations in several Antarctic studies (Palinkas et al. 2004; Palinkas and Houseal 2000; Peri et al. 2000; Reed et al. 2001; Xu et al. 2003). and reveals the severity of tensionanxiety, depression, anger-hostility, confusion, fatigue and vigor.

Sustained Attention to Response Task (SART) The SART is an attentional paradigm investigating inhibition and cognitive flexibility; the participants must click a button when a certain stimulus is presented on a computer screen (Manly et al. 1999).

Test of Everyday Attention (TEA) Here, we used the Auditory Elevator tasks only. These measure sustained and selective attention as well as cognitive flexibility (Robertson et al. 1996).

\section{Procedure}

Albert gave fully informed consent prior to his deployment to Svalbard. In order to collect all data, one of the authors (AGMT) traveled to the Polish Polar Station. Albert resided at the Polish Polar Station and was one of 10 participants there until he left after the Winter Isolation measurement (see Temp et al. 2017, 2018 for details). He was given the questionnaires in an anonymised envelope to fill in in his own time while at the station, and completed them online from home in April and June. The cognitive tests preceded the interviews, and both were done in person with AGMT at a time that was suitable to his work schedule at the station. The Controls were measured in the same seasons as Albert. 


\section{Ethical considerations}

All data was stored on a password-secured computer for the duration of the study. Their personal details were kept separately from the data analysis file at all times. All procedures of this study were in accordance with the Declaration of Helsinki, and the study was given ethical approval by the University of Edinburgh's Psychology Research Ethics Committee under reference number 216-1415/1. All participants consented to their individual, anonymised data collection and to the data publication as part of an unidentifiable group analysis. After it became clear, that Albert's data would provide its most thorough and helpful insights via a case study, we sought his repeated consent prior to publication of his data. We agreed on a pseudonym and the details to be published as part of AGMT's doctoral thesis.

\section{Analytical considerations}

\section{Qualitative data}

Our analytical process closely followed that described by Smith et al. (2009, pos. 1735ff), see Fig. 1.

Descriptive Comments summarise key aspects without immediate, intentional attempts at interpretation by the researcher. Linguistic Observations note Albert's feelings based on his use of filler noises or filler words, hesitant silences or laughter. These observations also included any use of metaphors and comparisons as well as other aspects of language such as word choices. Conceptual Questions move away from the Albert's explicit claims because the researcher's focus shifts towards a more overarching understanding of the material that is being discussed. Then, Important Phrases, Objects and Experiential Claims were determined. These steps yielded Emergent Themes, from which one lifeworld table was created per

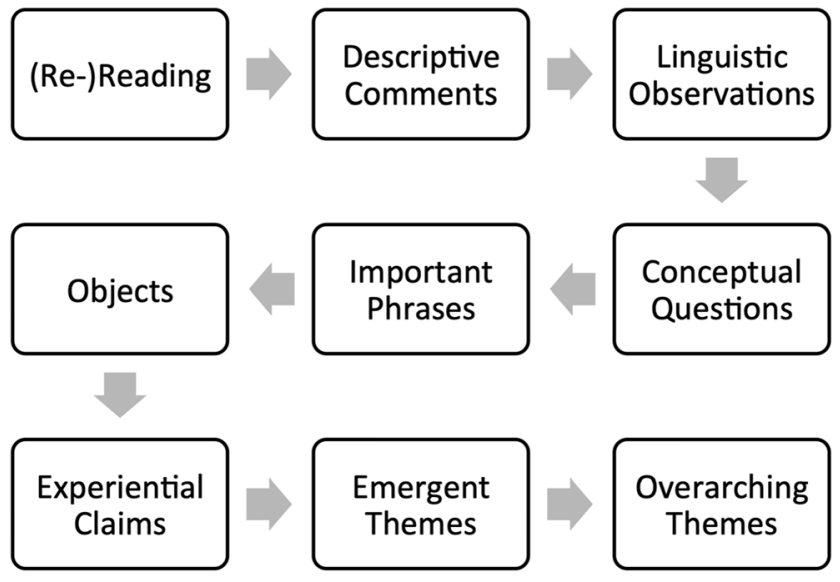

Fig. 1 The Analytical Process Behind IPA. Each stage of analysis is represented by a box. Each transcript was read once per stage with the exception of the theme stages interview. These focus on each person-in-context, relating to Heidegger's notion of humans as being out in the world with observable relationships to meaningful surroundings and context (Larkin et al. 2006).

\section{Quantitative data}

We employed Crawford et al.'s (2010) program Singlims_ES.exe. This program requires Albert's individual scores from the SCL-90-R, the POMS, the SART and the TEA; plus a control population's N, mean, and standard deviation (SD). We used not one but two control populations, the Explorers and the Controls, to learn how Albert's experience differed from other people at the station, and from other people of his own age in their home environment. From these metrics, Singlims ES.exe calculates the effect size $\mathrm{z}_{\mathrm{cc}}$ which estimates the average difference of Albert from the Controls and Explorers, measured in units of SD. The program additionally provides the $95 \%$ confidence interval for $\mathrm{z}_{\mathrm{cc}}$, the $\mathrm{t}$ value, the one-tailed $p$ value (Crawford and Howell 1998), the point estimate for Albert's abnormality and its $95 \%$ confidence interval (Crawford and Garthwaite 2002).

\section{Results}

The qualitative analyses precede the quantitative analyses because only they can answer the question of how Albert experienced the Polish Polar Station. A thorough understanding of Albert's lived experience is essential and quantitative methodology cannot provide a personal enough insight. In Albert's case, we let his lifeworld from January guide our decisions on which quantitative analyses to run: the hypotheses of the quantitative analyses were based on Albert's descriptions of his experience.

\section{Albert's Lifeworld in September}

Albert's lifeworld revolved around three themes: his life at the station, his life with his family at home, and the his co-workers at the station (Table 3).

Table 3 Albert's Emergent Themes in September

September themes and sub-themes

The Real "Me" at the Station

My Self As a Captive of the Hierarchy Not Even My Work is Free

The Ghost "Self" at Home

My Space in My Family

A Valuable Team

The Good Group

The Janitor 


\section{The real "me" at the station}

Here, Albert reflected on his life at the station, and on the complications it held for him

\section{My self as a captive of the hierarchy}

Albert's thoughts revolved around his struggles at the station. He found it difficult to be confined with his colleagues on a daily basis, and did not enjoy the Karol's authority over him. Even though Albert appreciated Karol as a person and a father figure at the station, Albert worried about his own coping with the hierarchy:

"And because I'm not a boss I have to, I have to fit to this system. I don't really like meeting every morning after, after breakfast and talking about what I'm gonna do and like...can explain myself. I hate explaining myself. [...] Hierarchy. So, this might be a problem. And also umm.. I sometimes, I sometimes just can't deal with the rules somebody says...like saying...so I don't like it. Sometimes I can say "I don't give a shit about the rules" and "I don't like it" so I won't, I won't do it. But I haven't done it for this, this two months. So I hope I'm not going to do it. But it's also a risk so that's why I said I might be problematic."

Albert felt imprisoned at the station because of its rigid hierarchy and schedules. Despite his dislike for this system, Albert liked Karol as a person and as his leader; and Albert liked his own work. He continuously made an effort to perform well and be what he considered a valuable team member (see The Good Group below). Albert's lack of autonomy over his personal and professional decisions was at the core of his experience, decreasing his job satisfaction and sense of achievement. He worried that he might cause team disruptions:

"well it might be problematic if you choose somebody who is 21 and well, in many cases I'm stupid child and I realise that fact. So it's a big responsibility, such a young guy and I think it is a big risk, right? Because if you're 30 or 40 , you more or less settle. But I'm 21 and still there is a big hurricane in my head so...so it's a bit risky to choose a young guy like me for one year, right? I think so."

Albert experienced himself as less settled and stable than his older colleagues. He saw himself as less mature and considered this a risk to the mission, alongside his dislike for the hierarchical system. It was clear, however, that Albert did not wish to cause any problems, he was merely anticipating them.

\section{Not even my work is free}

Albert was very dissatisfied with a particular team member's professional performance and how it affected his own life:
“And I don't want to do stupid jobs somebody else is supposed to do. Like this janitor! He has so many duties he doesn't do! Like taking this big heavy barrel of rubbish and throwing it to the fjord. He's supposed to do it! No, I did it last time! We did it with Konstantyn, so we went. We lost a part of the quad so we had to bring a certain metal finder, so we found it in the sea. It took like fucking...two hours! And I lost these two hours! And it wasn't even my duty to do it, right? I don't like it. I don't like when I have to do somebody else's job."

Here, it becomes clear that Albert did not enjoy being commanded to help someone whom he saw as lazy: the janitor. The janitor's lack of effort with his duties showed a disrespect for the system which Albert tried to fit into so desperately. He crossed Albert's personal and professional boundaries by making his own decisions to work or rest as he pleased, against the schedules and hierarchies of the station. These crossed boundaries upset Albert because someone else refused to adhere to rules which Albert also would have liked to do; but their refusal came with a lack of effort on the janitor's part. Albert very clearly defined his personal worth by his professional competence, will to work, and ability to entertain his team mates:

"I'm also a bit of a...well, as they called me once, a clown. But okay, I don't mind being a clown, if it's gonna help. If it's gonna be...starts to be a problem of some kind and it's gonna be uncomfortable for some people, of course I'm going to stop and be serious. Because I can. But...yeah...being let's say funny... which I don't...I don't find myself funny but when people laugh I'm okay with it."

Here, Albert demonstrated a clear will to fit in socially with his team: he was willing to contribute his sense of humor if the other Explorers wanted or needed it; but he was also willing subside if it would make their lives easier. Altogether, this shows that Albert was capable of managing his own behaviours to fit with the team. He was also very aware of the team's wants and needs, and was willing to contribute to them. The success of Albert's efforts was clear by the team's reactions towards him: they liked him, appreciated the quality of his work, and missed him after he eventually left.

\section{My ghost self at home}

This was Albert's self in relation to his life in Poland, and his relationship with his family and his partner. It is in stark contrast to his self at the station. While his self at the station was grounded in his work and his peer relations, his Ghost Self only participated loosely in his home life. 


\section{My space in my family}

Albert was previously unaware how much he would miss his family, and how difficult this would be for him:

"And one of the reasons I could say "Fuck this station, I'm coming back!" is that I'm going to miss my parents very, very much or my girlfriend very, very much. It's very hard to see your family in Skype and your dog and everything. And ahhh...I start to feel that I'm not, I'm not, I'm not a part of my family anymore. Because I'm absent. I'm just a ghost who appears from time to time in a computer. That's also a problem. So...I don't know. I really love my family, it's not like love but I need to be around them. I didn't realise that fact before I came here but now I know that it is a big issue in my life."

His lack of direct interactions and inability to engage in their daily activities such as meals led to an early-on disconnection from his family. Albert saw himself as a ghost because he could not contribute actively to their lives even though he would have chosen to do so. He felt somewhat powerless and disconnected. He had once had a place in his family where his Real Self had been: this was now being replaced by his Ghost Self because his Real Self was engaged at Hornsund. These feelings were exacerbated by the fact that he had no possibility to return in case of any family emergency which concerned him deeply:

"And all these thoughts that my grandfather can die because he's old and something can happen. It's not helping, it's not helping if you think and you you know that you won't be able to do anything. You just get this phone call from your family and my dad or my mum is going to tell "Albert, your grandfather is dead." What I'm gonna do? I can't get to the plane because I' $m$ in the middle of nowhere and even if I could, it's...that...the feeling that you can't go back even if you want, that is really tough."

His limited engagement with his home world led to his Ghost Self and the station life clashing: he made his best efforts to be a valuable team member. But at the same time, his emotional focus and engagement were very much with his family and partner, not at the station.

Altogether, this shows how torn Albert was between settling into his tasks at the station and maintaining the necessary emotional proximity to his family. This was a fragile balance for him to maintain, and it worried him.

\section{A valuable team}

Even though Albert was bored by the daily routines of people at the station and they did not provide entertainment, he appreciated most of his co-workers.

\section{The good group}

What he appreciated most were professional competence and friendliness. Albert gave some examples:

"Like Jan. He's a perfect personality for this kind of... adventure. Or Konstantyn. Or Elwira. Well, it's...maybe it's not about personality but it's also about the value that this person brings to the station. Because...people are always talking about personality. But if you're not a valuable person who can show off with knowledge or show a gain, it's really difficult. But if you are a valuable person, you can be sure that you're gonna be liked be the other members of the group. That is very important."

Albert valued his colleagues based on their active contributions to the team, rather than their innate personalities. It was important to him that they were competent at their jobs and worked hard because this helped to keep the station functional. While people's personalities might clash in their personal lives, keeping the station functional through their professional efforts was vital to everyone's survival and the team's professional success. Being liked by other team members depended on these efforts to become valuable.

\section{The janitor}

Albert felt frustrated that he had to step in to do the janitor's job instead of his own job or spending his free time on things he enjoyed (see the extract in Not Even My Work is Free above). Consequently, Albert also struggled with respecting the janitor:

"And the problem is this guy is, I think, from time to time he can't deal with the fact that he's a like...let's say janitor? And I'm doing my job and somebody is doing their job. And I think maybe he can't deal with it. So we had like smaller or bigger...Difficulties and arguments. [sighs] And that's really hard for me because I don't like to argue with people and I hate when somebody demands respect just because of his age. It's stupid for me because you... if you demand respect because of your age, there should be something behind this age. An experience like a knowledge of life or something like this. But if it's just the age it doesn't mean anything. Only means, it only means you living in this world 30 or 40 years more than me but it doesn't, doesn't mean that you're smarter or something. So I hate it, I hate it, I hate that the ....he always tries to show himself as the guy who knows best and it's really difficult for me."

The problem here was that Albert and the janitor were both at the same level of the station's hierarchy. However, the janitor treated Albert as if Albert were an inferior team member because of his younger age. Albert, however, felt that the janitor's age was not an appropriate reason for the janitor to 
elevate himself to a higher level. Albert's struggle was that the janitor was constantly suggesting improvements to Albert's work and behaviour when the janitor himself was not qualified to do so, not hierarchically positioned to do so, not valuable enough to the team to do so, and especially not invited to do so. This crossed important boundaries; the janitor did not complete his own tasks as the schedules demanded and elevated himself in the hierarchy and thus embodied everything that Albert saw as problematic: baseless authority, lack of competence, laziness, disinterest in Albert as a person, and increased self-interest.

Altogether, Albert experienced the station, its inhabitants and the daily life as challenging and stressful rather than the workload or the type of work. Settling into the station's routine, following a hierarchy and being separated from his family was also difficult for him. While many of the interpersonal interactions with most of his team members were very enjoyable, the janitor's unjustified and arrogant demeanor enraged Albert.

\section{Albert's Lifeworld in January}

Here, the Ghost Self from September had become so prominent that his life at the station had become a Ghost Life. Albert had detached himself emotionally from his colleagues and focused on his family whom he missed dearly. Albert's detachment stemmed from a lack of recognition of himself in his own mind. He could no longer focus and retain information which robbed him of his job satisfaction, the one thing he was thriving on in September. He was very aware of this and attempted to counteract it by studying and focusing on his research. Figure 2 outlines Albert's Ghost Life.

The most prominent aspect of Albert's experience Missing Thoughts - is at the top, the remaining ones are ordered in clock-wise direction.

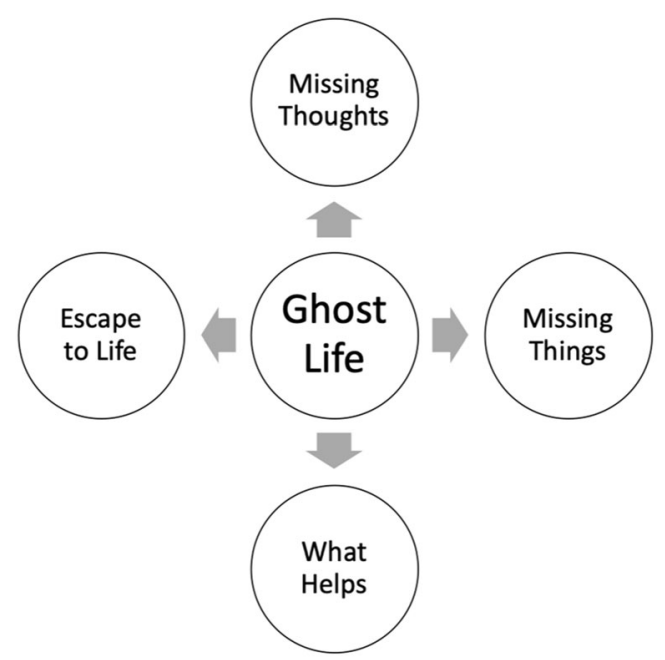

Fig. 2 Albert's Lifeworld in January

\section{Missing thoughts}

Much of Albert's experience revolved around his sense of loss of his own mind's activity:

“But I-I-I feel like I lost so so much. It's, it's like instead of studying it for three years, physics, it's like I just finished high school. (sighs) And I don't know what to do with it. Because sometimes...er...before I came here I...I...recognised myself as a rather smart person who knows some things and that that my brain...sometimes used to...well, ahm... amuse me and shock me in a good way. I...thought about things and I created things in my mind. I was kinda impressed but now it's, it's, it's nothing like that. The last good idea I had was two months ago. And now, I just feel like I'm everybody else, I'm not thinking, I'm just doing things I have to do. And there is nothing cool in my life anymore. I, I, I don't amuse myself; I-I don't say jokes to myself anymore. Of course, I, from time to time I laugh but it's mostly because of this situation not the imaginary situations I crused to create in my mind. Sooo... everything changed. Everything changed. Because I-I-I-I-I got stupid somehow. In-in-in three months, I got stupid."

He felt that he had lost much of his knowledge that he gained in his university degree which frustrated him in a professional sense. He felt as if he had become stupid, compared to September. And since his professional achievements were what gave him joy in September, this led to Albert losing the enjoyable aspects of his life at the station. Additionally, he had lost the ability to entertain himself in the face of the boredom of polar night's routines. Albert's profound sense of loss led to him desperately grieving for these abilities. He described that he struggled to retain anything that he read; this made it difficult to find entertainment as well as acquire professional knowledge through publications. The above extract shows that Albert - despite being proficient in English - stammered when discussion a particularly emotional topic. As he did not stammer in September, this is not indicative of a speech impediment, it is rather a sign of his emotional grief. Albert hoped that his cognitive abilities would return if he returned to his life in Poland, with his family and his university degree. He was, however, uncertain.

\section{Missing things}

Albert attributed some of the missing thoughts to missing aspects in his life, such as people to observe and wonder about.

"And also, people, I didn't realise that even watching people in a pub, in a tram, on a bus, on a street, 
everywhere that that creates thoughts. It creates thoughts. I don't have thoughts right now. I don't have thoughts! I used to have so many thoughts! "Why those people act like this?" "What do they do?" "Why do people walk like that?" And I thought. But now I don't, I don't think! I-I think only about stupid things. I have to do the measurement, I go do the measurement and that's it. And I go back and I lie down and I don't think. I can't stand this fucking emptiness."

Even though he had his colleagues at the station, they did not suffice to continuously inspire Albert's curiosity. Albert and all his colleagues had settled into their professional routines of fulfilling their duties which made life very boring for him: he knew what his colleagues where doing, when and why. This lack of wonder, and absence of people to wonder about, created an unpleasant emptiness in Albert's head. He was missing his thoughts as well as the aspects of his life that used to inspire new thoughts. He felt un-challenged and this lack of challenge what was made it difficult for him at the station. This new situation in his head made it very difficult for Albert to be happy at the station, he was clinging onto the hope that he would feel better soon. Additionally, his engagement with his colleagues had declined. This is similar to what Albert experienced in September: the established routine of the station's team bored him because everyone and everything was predictable. The team's interactions neither impaired nor improved his emotional state, even the conflict with the janitor had become meaningless to Albert.

\section{What helps}

Albert actively pursued scientific activities aside from his station duty so that he would feel better. These activities were future-oriented, for example he was writing research publications to boost his $\mathrm{CV}$, and university applications. They reminded him of the time when his cognitive faculties were still normal and simultaneously filled him with the hope of their return after the end of the mission. Additionally, Albert refused to participate in recreational alcohol consumption at the station because he feared that he would lose himself entirely if he did. When asked to rate these activities' importance to his well-being on a scale from 0 to 10 , he replied:

"Well...if I, if I didn't do them...I don't even wanna think what will happen to me so I'm gonna say 10 .

But... maybe it's very personal to look at that. You could say it's 0 or 1; but for me it's 10 because otherwise I really don't wanna think what's going to happen to me."

This shows that Albert perceived his own mental health as fragile. The biggest threat was the lack of input he experienced at the station because it facilitated a type of boredom and emptiness Albert found difficult to handle. Since this boredom was innate to the station, and the emptiness was innate to his mind, Albert attempted to fill his bored mind with researchcentered activities.

\section{Escape to life}

Albert considered an evacuation due to his problems. He wanted to return home, which was met with some resistance:

"When you deal with these problems and you realise what is most important thing in your life and that your ambition's to be...winterer or to be the youngest winterer, it all doesn't matter. And I don't, I don't consider my decision of leaving as a mistake, as they told me. And I know I'm not going to regret it. And I don't consider my decision to come here as a mistake because if I didn't came here, didn't come here, probably I wouldn't know as much about myself as I know now."

Karol - as Albert's team leader - was concerned for Albert's professional future and how an evacuation would affect Albert's chances of employment in Poland. Albert, however, was certain that leaving was his only choice to re-gain his happiness. He had realised that his family and his university life in Poland were of utmost importance to him and that his time at the station was wasted because it did not bring him any closer to his scientific goals. The station life brought him deprivation of stimulation, impaired capacities and even a loss of past accomplishments. Albert's wish to return home was profound and he could not see the point in remaining at the station.

Albert described a sensation of deprivation along a lack of fulfilment. He reported very little concern for or engagement with his peers at the station, but felt a deep longing for his home in Poland. He perceived the station life as boring and his own mind was unable to help him alleviate the boredom. This dysfunction was very distressing to Albert because he could no longer recognise himself in his own mind. While it did not affect the quality of his work it affected his quality of life and he made great efforts to improve his life at the station. We know the quality of his work was unaffected because if it had been, his team members would have either let him know, or complained about him privately as they did about another team member. He engaged in cognitively challenging research activities and focused on his future after the station. However, his loss of the ability to retain written words in his memory frustrated him. He was somewhat anxious that his cognitive faculties would not return because he did not see them as a result of the polar night.

Based on these, the hypotheses for the quantitative testing was that Albert would experience more Depression, Confusion, Psychoticism and Anxiety, as well as less Vigor 
than the other Explorers and his Case Controls. We excluded Anger, Fatigue or Tension because they were not immediately apparent in Albert's interviews (Table 4).

Effectively, Albert described his mood as more depressive than nearly $100 \%$ of both control populations; this indicated that his depression levels were unusually high for a Polish person wintering at Hornsund, and for a person of Albert's age, gender and educational background.

Albert experienced more Confusion than his colleagues at Equinox and during Winter Isolation. His Confusion was also higher in the Summer, when he was at home and they remained at the station. This fits with his own description of having a "big hurricane" in his head from September (see above) and also with his cognitive struggles over the polar night (Table 5).

In comparison to his Case Controls, he was more confused After Arrival, at Equinox, during Winter Isolation and in the Summer. While his suggestion of having a "big hurricane" in his head related to his young age in comparison to his fellow Explorers, his increased Confusion in comparison to peer-aged Case Controls requires a different explanation. Perhaps the combination of being so young and being at the station is what elevated Albert's levels of Confusion in comparison to both groups.

Only 2\% of Explorers reported such low levels of Vigor as Albert in Winter, while in Summer Albert reported more Vigor than $97 \%$. His lack of Vigor in Winter is consistent with Albert's self-description above (Table 6).

However, no differences between Albert and the Case Controls emerged. This suggests that while Albert was unusually low in his Vigor compared to the other Explorers, these low levels of Winter Vigor were to be expected in someone of his background.

The above analyses quantify Albert's claims of feeling desperate, confused, tense and anxious. While the SCL-90-R also contains sub-scales to measure these experiences, it would be redundant to re-run these analyses. Instead, Obsessive Compulsion was chosen from the SCL-90-R. Obsessive Compulsion here also includes the cognitive performance deficits (Derogatis 1994, p. 9) which Albert experienced. In our follow-up meetings after his Winter interview, Albert also described a lack of appetite; this item was not part of any of the sub-scales and was thus tested individually.

Altogether, Albert had more cognitive complaints than approximately $99 \%$ of the Explorers After Arrival, at Equinox and during the Winter Isolation.

While Albert rated his own cognitive deficits as significantly higher than his fellow Explorers and the Case Controls in the months presented in Table 7. This suggests that he believed his cognitive abilities to be worse than his fellow Explorers did. It is notable that the Case Controls did not fluctuate at all in their experience of their abilities while the Explorers fluctuated somewhat.

The next item, Albert's appetite, was analysed only for Winter Isolation because this was the only time he complained of appetite-related issues (Table 8).

This shows that Albert's appetite was poorer than approximately $100 \%$ of the Explorers. It was not possible to test his appetite in comparison to his Case Controls because Singlims_ES.exe requires a positive SD and the Case Controls produced a mean of 0 with an SD of 0 on this item.

Table 4 Albert felt more depressed than the explorers and his case controls after arrival, equinox, and winter isolation

\begin{tabular}{|c|c|c|c|c|c|c|c|c|c|c|}
\hline \multirow[t]{2}{*}{ Season } & \multicolumn{3}{|c|}{ Explorers } & \multirow[t]{2}{*}{ Albert } & \multicolumn{2}{|c|}{ Significance Test } & \multicolumn{2}{|c|}{$\begin{array}{l}\text { Estimated percentage of the } \\
\text { Explorers obtaining } \\
\text { a lower score than Albert }\end{array}$} & \multicolumn{2}{|c|}{$\begin{array}{l}\text { Estimated effect } \\
\quad \operatorname{size}\left(\mathrm{z}_{\mathrm{cc}}\right)\end{array}$} \\
\hline & $\mathrm{N}$ & Mean & SD & & $\mathrm{t}$ & $\mathrm{p}$ & Point & $95 \% \mathrm{CI}$ & Point & $\mathrm{CI}$ \\
\hline After Arrival** & 9 & 2.22 & 3.15 & 13 & 3.25 & .006 & 99.41 & 94.99 to 99.999 & 3.42 & 1.64 to 5.18 \\
\hline Equinox $* * *$ & 9 & 1.22 & 1.30 & 16 & 10.79 & $<.001$ & 99.99 & 100.00 to 100.00 & 11.37 & 5.89 to 16.87 \\
\hline Winter Isolation $* * *$ & 9 & 2.00 & 2.35 & 16 & 5.65 & $<.001$ & 99.98 & 99.88 to 100.00 & 5.96 & 3.03 to 8.89 \\
\hline Spring & 9 & 2.33 & 2.45 & 4 & 0.65 & .268 & 73.20 & 47.36 to 91.87 & 0.68 & -0.07 to 1.40 \\
\hline Before Departure & 9 & 1.56 & 2.19 & 4 & 1.06 & .161 & 83.93 & 59.82 to 97.38 & 1.11 & 0.25 to 1.94 \\
\hline \multirow[t]{2}{*}{ Season } & \multicolumn{3}{|c|}{ Case Controls } & Albert & \multicolumn{2}{|c|}{ Significance Test } & \multicolumn{2}{|c|}{$\begin{array}{l}\text { Estimated percentage of the } \\
\text { Case Controls obtaining } \\
\text { a lower score than Albert }\end{array}$} & \multicolumn{2}{|c|}{$\begin{array}{l}\text { Estimated effect } \\
\quad \text { size }\left(\mathrm{z}_{\mathrm{cc}}\right)\end{array}$} \\
\hline & $\mathrm{N}$ & Mean & SD & & $\mathrm{t}$ & $\mathrm{p}$ & Point & $95 \% \mathrm{CI}$ & Point & CI \\
\hline After Arrival** & 6 & 1.82 & 1.72 & 13 & 6.02 & .001 & 99.91 & 99.46 to 100.00 & 6.50 & 2.55 to 10.48 \\
\hline Equinox $\mathrm{x}^{\mathrm{a}^{* * * *}}$ & 6 & 1.82 & 1.72 & 16 & 7.63 & $<.001$ & 99.97 & 99.95 to 100.00 & 8.24 & 3.28 to 13.26 \\
\hline Winter Isolation ${ }^{1 * * *}$ & 6 & 1.82 & 1.72 & 16 & 7.63 & $<.001$ & 99.97 & 99.95 to 100.00 & 8.24 & 3.28 to 13.26 \\
\hline Spring & 6 & 1.83 & 1.72 & 4 & 1.15 & .151 & 84.85 & 54.61 to 98.94 & 1.24 & 0.12 to 2.30 \\
\hline Before Departure & 6 & 1.83 & 1.72 & 4 & 1.15 & .151 & 84.85 & 54.61 to 98.94 & 1.24 & 0.12 to 2.30 \\
\hline
\end{tabular}

$* p<.05, * * p<.01, * * * p<.001$

${ }^{a}$ The Case Controls' average for Equinox and Winter Isolation are identical because Albert's Time Control reported the same level of Depression at these points. Because Albert's score was also identical at these points, the results for them are the same 
Table 5 Albert felt more confused than the explorers and his case controls

\begin{tabular}{|c|c|c|c|c|c|c|c|c|c|c|}
\hline \multirow[t]{2}{*}{ Season } & \multicolumn{3}{|c|}{ Explorers } & \multirow[t]{2}{*}{ Albert } & \multicolumn{2}{|c|}{ Significance Test } & \multicolumn{2}{|c|}{$\begin{array}{l}\text { Estimated percentage } \\
\text { of the Explorers obtaining } \\
\text { a lower score than Albert }\end{array}$} & \multicolumn{2}{|c|}{$\begin{array}{l}\text { Estimated effect } \\
\quad \text { size }\left(\mathrm{z}_{\mathrm{cc}}\right)\end{array}$} \\
\hline & $\mathrm{N}$ & Mean & SD & & $\mathrm{t}$ & $\mathrm{p}$ & Point & $95 \% \mathrm{CI}$ & Point & $95 \% \mathrm{CI}$ \\
\hline After Arrival & 9 & 7.00 & 2.65 & 9 & 0.72 & .247 & 75.28 & 49.58 to 93.12 & 0.76 & -0.01 to 1.48 \\
\hline Equinox** & 9 & 3.00 & 2.12 & 13 & 4.48 & .001 & 99.90 & 99.08 to 100.00 & 4.72 & 2.36 to 7.07 \\
\hline Winter Isolation** & 9 & 4.22 & 1.56 & 12 & 4.73 & .001 & 99.93 & 99.38 to 100.00 & 4.99 & 2.50 to 7.46 \\
\hline Spring & 9 & 3.78 & 2.11 & 5 & 0.55 & .299 & 70.09 & 44.16 to 89.86 & 0.58 & -0.15 to 1.27 \\
\hline Before Departure* & 9 & 2.89 & 2.32 & 8 & 2.09 & .035 & 96.50 & 82.69 to 99.97 & 2.20 & 0.94 to 3.43 \\
\hline \multirow[t]{2}{*}{ Season } & \multicolumn{3}{|c|}{ Case Controls } & Albert & \multicolumn{2}{|c|}{ Significance Test } & \multicolumn{2}{|c|}{$\begin{array}{l}\text { Estimated percentage } \\
\text { of the Case Controls obtaining } \\
\text { a lower score than Albert }\end{array}$} & \multicolumn{2}{|c|}{$\begin{array}{l}\text { Estimated effect } \\
\quad \text { size }\left(\mathrm{z}_{\mathrm{cc}}\right)\end{array}$} \\
\hline & $\mathrm{N}$ & Mean & SD & & $\mathrm{t}$ & $\mathrm{p}$ & Point & $95 \% \mathrm{CI}$ & Point & $\mathrm{CI}$ \\
\hline After Arrival* & 6 & 2.83 & 1.72 & 9 & 3.32 & .010 & 98.95 & 90.15 to 100.00 & 3.59 & 1.29 to 5.87 \\
\hline Equinox $* *$ & 6 & 2.83 & 1.72 & 13 & 5.47 & .001 & 99.86 & 98.94 to 100.00 & 5.91 & 2.30 to 9.55 \\
\hline Winter Isolation** & 6 & 3.17 & 1.72 & 12 & 4.75 & .003 & 99.75 & 97.56 to 100.00 & 5.13 & 1.97 to 8.31 \\
\hline Spring & 6 & 2.83 & 1.72 & 5 & 1.17 & .148 & 85.23 & 55.12 to 99.02 & 1.26 & 0.13 to 2.36 \\
\hline Before Departure* & 6 & 3.00 & 1.67 & 8 & 2.77 & .020 & 98.04 & 84.57 to 100.00 & 2.99 & 1.02 to 4.95 \\
\hline
\end{tabular}

$* p<.05, * * p<.01, * * * p<.001$

" 0 " means that in the past week, they experienced no poor appetite at all. Effectively, this means that Albert's appetite was worse than theirs.

In January, Albert's concerns about his declined cognitive faculties concentrated on his lack of new ideas but also on his inability to retain verbally acquired information. Following this, we used Crawford and Garthwaite's (2002) RDSM_ES.exe program to test for the statistical significance of these changes. We did not find any. This shows how greatly any individual's experience of themselves in an Arctic environment can differ from a quantitative measure of their experience: while Albert despaired over his inability to focus and remember things, and worried whether he would ever be able to do so again, his tests showed that his cognition remained unaffected.

Altogether, these results unveil a young man who was deeply plagued by his isolation from his core family and his life goals to the point where he manifested psychosomatic symptoms such as weight loss and observable psychomotor retardation consistent with depression. Altogether, this provides a novel insight into psychological dysfunction during polar expeditions that has not yet been objectified scientifically.

Table 6 Albert experienced lower levels of vigor than his fellow explorers but higher levels of vigor than the case controls

\begin{tabular}{|c|c|c|c|c|c|c|c|c|c|c|}
\hline \multirow[t]{2}{*}{ Season } & \multicolumn{3}{|c|}{ Explorers } & \multirow[t]{2}{*}{ Albert } & \multicolumn{2}{|c|}{ Significance Test } & \multicolumn{2}{|c|}{$\begin{array}{l}\text { Estimated percentage } \\
\text { of the Explorers obtaining } \\
\text { a lower score than Albert }\end{array}$} & \multicolumn{2}{|c|}{$\begin{array}{l}\text { Estimated effect } \\
\text { size }\left(\mathrm{z}_{\mathrm{cc}}\right)\end{array}$} \\
\hline & $\mathrm{N}$ & Mean & $\mathrm{SD}$ & & $\mathrm{t}$ & $\mathrm{p}$ & Point & $95 \% \mathrm{CI}$ & Point & CI \\
\hline After Arrival & 9 & 10.44 & 5.53 & 10 & -0.08 & .471 & 47.08 & 23.33 to 71.81 & -0.08 & -0.73 to 0.58 \\
\hline Equinox & 9 & 10.22 & 6.08 & 6 & -0.66 & .265 & 26.43 & 7.91 to 52.26 & -0.69 & -1.41 to 0.06 \\
\hline Winter Isolation* & 9 & 8.67 & 1.87 & 4 & -2.37 & .022 & 2.27 & 0.01 to 13.22 & -2.50 & -3.85 to -1.12 \\
\hline Spring & 9 & 6.56 & 4.45 & 14 & 1.59 & .076 & 92.43 & 73.12 to 99.64 & 1.67 & 0.62 to 2.69 \\
\hline Before Departure* & 9 & 6.56 & 4.16 & 16 & 2.15 & .032 & 96.83 & 83.69 to 99.98 & 2.27 & 0.98 to 3.52 \\
\hline \multirow[t]{2}{*}{ Season } & \multicolumn{3}{|c|}{ Case Controls } & Albert & \multicolumn{2}{|c|}{ Significance Test } & \multicolumn{2}{|c|}{$\begin{array}{l}\text { Estimated percentage } \\
\text { of the Case Controls obtaining } \\
\text { a lower score than Albert }\end{array}$} & \multicolumn{2}{|c|}{$\begin{array}{l}\text { Estimated effect } \\
\text { size }\left(\mathrm{z}_{\mathrm{cc}}\right)\end{array}$} \\
\hline & $\mathrm{N}$ & Mean & $\mathrm{SD}$ & & $\mathrm{t}$ & $\mathrm{p}$ & Point & $95 \% \mathrm{CI}$ & Point & $\mathrm{CI}$ \\
\hline After Arrival* & 6 & 2.83 & 1.72 & 9 & 3.32 & .010 & 98.95 & 90.15 to 100.00 & 3.59 & 1.29 to 5.87 \\
\hline Equinox $* *$ & 6 & 2.83 & 1.72 & 13 & 5.47 & .001 & 99.86 & 98.94 to 100.00 & 5.91 & 2.30 to 9.55 \\
\hline Winter Isolation** & 6 & 3.17 & 1.72 & 12 & 4.75 & .003 & 99.75 & 97.56 to 100.00 & 5.13 & 1.97 to 8.31 \\
\hline Spring & 6 & 2.83 & 1.72 & 5 & 1.17 & .148 & 85.23 & 55.12 to 99.02 & 1.26 & 0.13 to 2.36 \\
\hline Summer* & 6 & 3.00 & 1.67 & 8 & 2.77 & .020 & 98.04 & 84.57 to 100.00 & 2.99 & 1.02 to 4.95 \\
\hline
\end{tabular}

$* p<.05, * * p<.01, * * * p<.001$ 
Table 7 Albert experienced more subjective cognitive deficits than the explorers and case controls

\begin{tabular}{|c|c|c|c|c|c|c|c|c|c|c|}
\hline \multirow[t]{2}{*}{ Season } & \multicolumn{3}{|c|}{ Explorers } & \multirow[t]{2}{*}{ Albert } & \multicolumn{2}{|c|}{ Significance Test } & \multicolumn{2}{|c|}{$\begin{array}{l}\text { Estimated percentage } \\
\text { of the Explorers obtaining } \\
\text { a lower score than Albert }\end{array}$} & \multicolumn{2}{|c|}{$\begin{array}{l}\text { Estimated effect } \\
\quad \text { size }\left(\mathrm{z}_{\mathrm{cc}}\right)\end{array}$} \\
\hline & $\mathrm{N}$ & Mean & SD & & $\mathrm{t}$ & $\mathrm{p}$ & Point & $95 \% \mathrm{CI}$ & Point & $95 \% \mathrm{CI}$ \\
\hline After Arrival ${ }^{* * *}$ & 9 & 1.67 & 2.06 & 18 & 7.52 & $<.001$ & 99.99 & 99.99 to 100.00 & 7.93 & 4.07 to 11.79 \\
\hline Equinox* & 9 & 4.44 & 5.43 & 21 & 2.89 & .010 & 99.00 & 92.42 to 100.00 & 3.05 & 1.43 to 4.64 \\
\hline Winter Isolation** & 9 & 4.33 & 3.81 & 23 & 4.65 & .001 & 99.92 & 99.30 to 100.00 & 4.90 & 2.46 to 7.33 \\
\hline Spring & 9 & 4.89 & 5.71 & 4 & -0.15 & .444 & 44.37 & 20.98 to 69.43 & -0.15 & -0.81 to 0.51 \\
\hline Before Departure & 9 & 3.77 & 5.16 & 9 & 0.96 & .183 & 81.78 & 57.10 to 96.48 & 1.01 & 0.18 to 1.81 \\
\hline \multirow[t]{2}{*}{ Season } & \multicolumn{3}{|c|}{ Case Controls } & Albert & \multicolumn{2}{|c|}{ Significance Test } & \multicolumn{2}{|c|}{$\begin{array}{l}\text { Estimated percentage } \\
\text { of the Case Controls obtaining } \\
\text { a lower score than Albert }\end{array}$} & \multicolumn{2}{|c|}{$\begin{array}{l}\text { Estimated effect } \\
\text { size }\left(\mathrm{z}_{\mathrm{cc}}\right)\end{array}$} \\
\hline & $\mathrm{N}$ & Mean & SD & & $\mathrm{t}$ & $\mathrm{p}$ & Point & $95 \% \mathrm{CI}$ & Point & $95 \% \mathrm{CI}$ \\
\hline After Arrival* & 6 & 4.67 & 4.55 & 18 & 2.71 & .021 & 97.89 & 83.84 to 99.99 & 2.93 & 0.98 to 4.85 \\
\hline Equinox* & 6 & 4.67 & 4.55 & 21 & 3.32 & .010 & 98.95 & 90.17 to 100.00 & 3.59 & 1.29 to 5.88 \\
\hline Winter Isolation** & 6 & 4.67 & 4.55 & 23 & 3.73 & .007 & 99.32 & 93.16 to 100.00 & 4.03 & 1.49 to 6.57 \\
\hline Spring & 6 & 4.67 & 4.55 & 4 & -0.14 & .448 & 44.84 & 17.23 to 74.69 & -0.15 & -0.95 to 0.67 \\
\hline Before Departure & 6 & 4.67 & 4.55 & 9 & 0.88 & .209 & 79.07 & 47.53 to 97.17 & 0.95 & -0.07 to 1.91 \\
\hline
\end{tabular}

$* p<.05, * * p<.01, * * * p<.001$

\section{The "intervention"}

We would like to preface this section by stating that the intervention delivered to Albert was not premeditated or clinically administered in any way because case studies like this one cannot be planned in advance. There is no careful monitoring of Albert's adherence to the intervention or measurement of length of treatment. Therefore, this is not a clinical evaluation of the presented intervention's efficacy. However, we believe that the attempted intervention - emotional freedom techniques (EFT) - is worth further investigations in polar settings.

After his January interview, Albert asked AGMT for regular, private meetings with the goal of alleviating his feelings of distress and working towards a safe evacuation in the spring. He was certain that his state would not improve. Albert and his team leader voiced serious concerns over Albert's mental well-being and his physical well-being with regard to his unwanted weight loss and his request for evacuation to AGMT. After conferring with the team leader, AGMT agreed to these private meetings. AGMT and Albert discussed his most distressful feelings in these meetings; these were anxiety that his partner might leave him, anxiety that his grandfather - who was healthy at the time - might die, and concerns over his unwanted loss of weight and appetite. They also discussed the extent of his despair for evacuation which made him consider forcing an evacuation medically. During the meetings, Albert was shown EFT using a manual (Ortner 2013). EFT is an acupressure technique whereby the person taps certain points on their body lightly with their fingers while focusing on an unwanted thought or feeling which they want to alleviate. EFT has been shown to be efficient in reducing depression in college students (Church et al. 2012a) and in reducing depression as well as cortisol levels in the general population (Church et al. 2012b). After the meetings, he went to apply the technique in his native Polish language which he found to be more effective than in English. After 1 week of tapping with EFT, Albert happily reported a $1.5 \mathrm{~kg}$ weight gain and an alleviation of many of his worries. Ethical approval had not been sought for the intervention described. While AGMT had been trained
Table 8 Albert experienced a reduced appetite in comparison to his fellow explorers

\begin{tabular}{|c|c|c|c|c|c|c|c|c|c|c|}
\hline \multirow[t]{2}{*}{ Season } & \multicolumn{3}{|c|}{ Explorers } & \multirow[t]{2}{*}{ Albert } & \multicolumn{2}{|c|}{$\begin{array}{l}\text { Significance } \\
\text { Test }\end{array}$} & \multicolumn{2}{|c|}{$\begin{array}{l}\text { Estimated percentage } \\
\text { of the Explorers } \\
\text { obtaining a lower } \\
\text { score than Albert }\end{array}$} & \multicolumn{2}{|c|}{$\begin{array}{l}\text { Estimated effect } \\
\text { size }\end{array}$} \\
\hline & $\mathrm{N}$ & Mean & SD & & $\mathrm{t}$ & $\mathrm{p}$ & Point & $95 \% \mathrm{CI}$ & Point & CI \\
\hline $\begin{array}{l}\text { Winter } \\
\quad \text { Isolatio- } \\
\mathrm{n}^{* * *}\end{array}$ & 9 & 0.11 & 0.33 & 3 & 8.31 & $<.001$ & 100.00 & $\begin{array}{r}100.00 \text { to } \\
100.00\end{array}$ & 8.76 & $\begin{array}{l}4.51 \text { to } \\
13.01\end{array}$ \\
\hline
\end{tabular}


to apply EFT, she had not been trained to teach EFT.It is stressed that the assistance was neither planned nor clinical in nature. A personal judgement was made by the researcher in the extreme situation to provide support and assistance to a crew member who requested assistance and was in distress. Although against the planned experimental protocol we have included these events in the case study as described and the informal use of EFT to help alleviate distress.

On March 1, Albert was evacuated from the Polish Polar Station by his own choosing. He continued to fill in the questionnaires analysed above and all his scores returned to a level that was not statistically significant from his former colleagues at the station or the control group. After his return home, Albert was asked to evaluate the intervention via online survey. Please see Fig. 3 below for the results.

Albert's comments were "I think [EFT] might help but I am pretty sure tapping without talking to You and analyzing the problems wouldn't be that efficient." and "THANKS A MILLION.: )". This follow-up shows that some of the depressive symptoms that may come with isolation from home, and with polar night, may be alleviated using EFT. EFT is selfadministered, easy to learn and safe to use even for lay people. However, Albert also clearly indicates the importance of the working relationship with the psychologist.

\section{Discussion}

Wintering at an isolated polar research station can come with considerable psychological distress. In Albert's case, his distress was rooted in his lack of job satisfaction, his isolation from his loved ones at home, and his feeling of displacement and emptiness at the station. He felt as if he had lost himself because in his experience, his cognitive abilities had declined to a point beyond recognition. This diminished his ability to engage in scientific outputs that he regarded as vital to his identity and future. While his emotional symptomatology was quantifiable, his experienced cognitive decline could not be substantiated. Nevertheless, Albert was thoroughly miserable at the Polish Polar Station. It must be noted that Albert was well-liked and seen as well-integrated by his colleagues. His emotional misery did not affect his work performance in anyone's opinion except his own.

The results of this case study are not intended as generalisable to other extreme environment populations at this stage: they serve as an inspiration to include case studies in the literature rather than to omit evacuated participants entirely (provided the participant consents to publication). However, this study's comprehensive approach of phenomenological interviewing, mental health assessment and cognitive testing provides a thorough insight into Albert's experience. It illuminates his life at the station from three angles and shows us that while his subjective suffering was immense, his perceived cognitive decline was not factual in the tests. This present work draws its relevance from its uniqueness but also from its depth of insight: for the first time, a scientific understanding of a polar psychiatric evacuation can be gained. Albert's closing comments also suggest that adding psychologists - not just medics - to polar expeditions may be worthwhile.

The safety issue at hand here is that cases like Albert's can result in severe team disruptions as outlined by Roberts (2014) for the Heroic Age cases, and even attempted or successful suicides of the afflicted individuals (Guly 2012). For the past few decades, the approach of all polar research institutes has been to select people out who are unsuitable, and to select in those who are highly suitable. These procedures have changed over time and must be taken with a grain of salt; for example Taylor (1969) stated that the New Zealand Antarctic Division rejected all applicants who were "psychotic, neurotic, homosexual and eccentric" (p. 83). Grant et al. (2007) give details on the modern British Antarctic Survey selection strategies, including multiple interviews by previous Antarctic personnel, psychometric and cognitive testing. However, it seems that all these strategies of prevention have had limited success because cases like Albert's still occur at different stations, different poles and in different cultures (see Palinkas and Suedfeld 2008).
Fig. 3 The helpfulness of EFT on Albert's depressive symptoms

\section{On a scale of 1-10, how helpful was EFT with regard to your....}

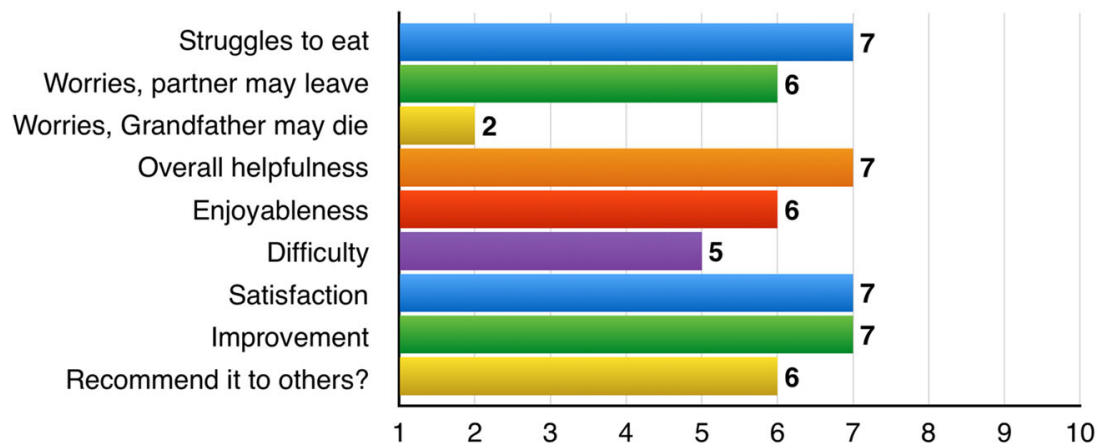




\section{Limitations}

We did not expect any of our participants to develop such severe psychological distress and were not prepared to intervene. The "intervention" as such was an improvised emergency measure and as such, cannot be considered a clinical application or trial. As we stated above, we do not claim that our results with EFT are generalisable beyond Albert's single case. Hence, we have included them in the section below.

\section{Future research}

We propose that to address this threat of severe mental illness, it is time to add intervention to prevention. To date, there is not enough empirically documented and reported evidence in the literature to draw conclusions with regard to how individuals and teams may be affected, and which interventions may be feasible and effective. Feasibility of any behavioural research is greatly affected by the remoteness of polar stations (Lugg 1991), but it might perhaps be cost-effective to teach interventive strategies such as EFT prior to deployment. In order to decide which interventive strategy to teach, further research into this niche is urgently required.

\section{Compliance with ethical standards}

Disclosure of potential conflicts of interest: none. The data for this publication were collected by author AGMT as part of her PhD thesis. Parts of the $\mathrm{PhD}$ thesis have been re-used for this publication. The study was partially supported by the Moray Endowment Fund with a grant of $£ 2000$ while the Institue of Geophysics, Warsaw offered access to the Polish Polar Station on Svalbard. The Institute of Geophysics and the University of Silesia awarded AGMT a conference grant of $£ 600$ to attend Arctic Circle 2017 in Reykjavik, Iceland. No grant numbers are available for these student grants.

All procedures performed in studies involving human participants were in accordance with the ethical standards of the institutional and/or national research committee and with the 1964 Helsinki declaration and its later amendments or comparable ethical standards.

Open Access This article is licensed under a Creative Commons Attribution 4.0 International License, which permits use, sharing, adaptation, distribution and reproduction in any medium or format, as long as you give appropriate credit to the original author(s) and the source, provide a link to the Creative Commons licence, and indicate if changes were made. The images or other third party material in this article are included in the article's Creative Commons licence, unless indicated otherwise in a credit line to the material. If material is not included in the article's Creative Commons licence and your intended use is not permitted by statutory regulation or exceeds the permitted use, you will need to obtain permission directly from the copyright holder. To view a copy of this licence, visit http://creativecommons.org/licenses/by/4.0/.

\section{References}

Bell J, Garthwaite PH (1987) The psychological effects of service in British Antarctica: a study using the General Health Questionnaire. Br J Psychiatry 150:213-218. https://doi.org/10.1192/bjp.150.2.213
Blair SM (1991) The Antarctic experience. In: Harrison AA, Clearwater YA, McKay C (eds) From Antarctica to outer space: life in isolation and confinement, 1st edn. Springer Verlag New York, Inc., New York, pp 57-64

Church D, De Asis MA, Brooks AJ (2012a) Brief group intervention using emotional freedom techniques for depression in college students: a randomized controlled trial. Depress Res Treat 2012:1-7. https://doi.org/10.1155/2012/257172

Church D, Yount G, Brooks AJ (2012b) The effect of emotional freedom techniques on stress biochemistry: a randomized controlled trial. J Nerv Ment Dis 200:891-896. https://doi.org/10.1097/NMD. 0b013e31826b9fc1

Crawford JR, Garthwaite PH (2002) Investigation of the single case in neuropsychology: confidence limits on the abnormality of test scores and test score differences. Neuropsychologia 40:1196-1208

Crawford JR, Howell DC (1998) Comparing an individual's test score against norms derived from small samples. Clin Neuropsychologist 12:482-486. https://doi.org/10.1076/clin.12.4.482.7241

Crawford JR, Garthwaite PH, Porter S (2010) Point and interval estimates of effect sizes for the case-controls design in neuropsychology: rationale, methods, implementations, and proposed reporting standards. Cogn Neuropsychol 27:245-260. https://doi.org/10.1080/ 02643294.2010.513967

Creswell JW, Plano Clark VL (2011) Designing and conducting mixed methods research, 2nd edn. SAGE Publications, Los Angeles

Derogatis LR (1994) Symptom Checklist-90-R: Administration, Scoring \& Procedure Manual for the Revised Version of the SCL-90. Minneapolis: National Computer Systems

Grant I et al (2007) Psychological selection of Antarctic personnel: the "SOAP" instrument. Aviat Space Environ Med 78:793-800

Guly H (2012) Psychiatric illness and suicide in the heroic age of Antarctic exploration. Hist Psychiatry 23:206-215. https://doi.org/ 10.1177/0957154X11399209

INTERACT (2014) INTERACT: Management planning for arctic and northern alpine research stations - examples of good practices. Aarhus University, Denmark: Aarhus University, Danish Centre for Environment and Energy

Larkin M, Watts S, Clifton E (2006) Giving voice and making sense in interpretative phenomenological analysis. Qual Res Psychol 3(2): $102-120$

Levesque M (1991) An experiential perspective on conducting social and behavioral research at Antarctic research stations. In: Harrison AA, Clearwater YA, McKay C (eds) From Antarctica to outer space: life in isolation and confinement, 1st edn. Springer Verlag New York, Inc., New York, pp 15-20

Lugg DJ (1991) Current international human factors research in Antarctica. In: Harrison AA, Clearwater YA, McKay C (eds) From Antarctica to outer space: life in isolation and confinement, 1st edn. Springer Verlag New York, Inc., New York, pp 31-42

Manly T, Robertson IH, Galloway M, Hawkins K (1999) The absent mind:: further investigations of sustained attention to response. Neuropsychologia 37:661-670. https://doi.org/10.1016/S00283932(98)00127-4

Norris K, Steel GD, Leane E (2018) In from the Cold? Interdisciplinary perspectives on the case of Sidney Jeffryes. In: POLAR2018

Norwegian Polar Institute (2005) Polar Bears in Svalbard

Ortner N (2013) The Tapping Solution: A Revolutionary System for Stress-Free Living. Carlsbad, CA: Hay House

Palinkas LA (1990) Psychosocial effects of adjustment in Antarctica lessons for long-duration spaceflight. J Spacecraft Rockets 27: 471-477. https://doi.org/10.2514/3.26167

Palinkas LA (2003) The psychology of isolated and confined environments: understanding human behavior in Antarctica. Am Psychol 58:353-363. https://doi.org/10.1037/0003-066X.58.5.353 
Palinkas LA, Houseal M (2000) Stages of Change in Mood and Behavior During a Winter in Antarctica. Environ Behav 32:128-141. https:// doi.org/10.1177/00139160021972469

Palinkas LA, Suedfeld P (2008) Psychological effects of polar expeditions. Lancet 371:153-163. https://doi.org/10.1016/S01406736(07)61056-3

Palinkas LA, Cravalho M, Browner D (1995) Seasonal variation of depressive symptoms in Antarctica. Acta Psychiatr Scand 91:423-429. https://doi.org/10.1111/j.1600-0447.1995.tb09803.x

Palinkas LA, Johnson JC, Boster JS, Rakusa-Suszczewski S, Klopov VP, $\mathrm{Fu} X Q$, Sachdeva U (2004) Cross-cultural differences in psychosocial adaptation to isolated and confined environments. Aviat Space Environ Med 75:973-980

Palinkas LA, Reedy KR, Shepanek M, Reeves D, Samuel Case H, Van Do N, Lester Reed H (2010) A randomized placebo-controlled clinical trial of the effectiveness of thyroxine and triiodothyronine and short-term exposure to bright light in prevention of decrements in cognitive performance and mood during prolonged Antarctic residence. Clin Endocrinol 72:543-550. https://doi.org/10.1111/j.13652265.2009.03669.x

Pattarini JM, Scarborough JR, Sombito VL, Parazynski SE (2016) Primary care in extreme environments: medical clinic utilization at Antarctic stations, 2013-2014. Wilderness Environ Med 27:69-77. https://doi.org/10.1016/j.wem.2015.11.010

Peri A, Scarlata C, Barbarito M (2000) Preliminary studies on the psychological adjustment in the Italian antarctic summer campaigns. Environ Behav 32:72-83. https://doi.org/10.1177/ 00139160021972432

Pope FE, Rogers TA (1968) Some psychiatric aspects of an arctic survival experiment. A clinical note on thirteen scientists. J Nerv Ment Dis 146:433-445

Reed HL et al (2001) Impairment in cognitive and exercise performance during prolonged Antarctic residence: effect of Thyroxine supplementation in the Polar Triiodothyronine syndrome. J Clin
Endocrinol Metab 86:110-116. https://doi.org/10.1210/jcem.86.1. 7092

Roberts D (2014) Alone on the ice: the greatest survival story in the history of exploration, First edition edn. W.W. Norton \& Company, New York

Robertson IH, Ward T, Ridgeway V, Nimmo-Smith I (1996) The structure of normal human attention: the test of everyday attention. Journal of the International Neuropsychological Society: JINS 2:525-534

Smith JA, Flowers P, Larkin M (2009) Interpretative phenomenological analysis: theory, method and research. SAGE, Los Angeles

Steel GD, Suedfeld P, Peri A, Palinkas LA (1997) People in high latitudes: the "big five" personality characteristics of the circumpolar sojourner. Environ Behav 29:324-347. https://doi.org/10.1177/ 001391659702900302

Strange RE, Klein WJ (1973) Emotional and social adjustment of recent US winter-over parties in isolated Antarctic stations. In Polar Human Biology: The Proceedings of the SCAR/IUPS/IUBS Symposium on Human Biology and Medicine in the Antarctic

Taylor AJW (1969) Ability, stability and social adjustment among Scott base personnel, Antarctica. Occup Psychol 43:81-93

Temp AGM, Lee B, Bak TH (2017) Well-being at the polish Polar Station, Svalbard: adaptation to extreme environments. In: Latola $\mathrm{K}$, Savela $\mathrm{H}$ (eds) The Interconnected Arctic - UArctic Congress 2016. pp 203-2010

Temp AGM, Lee B, Bak TH (2018) A mixed-methods approach in the Arctic archipelago of Svalbard: studying the cognition, mental health, and lived experiences of small teams in isolation and confinement. SAGE publications 1td, 1 Oliver's yard, 55 City road, London EC1Y 1SP United Kingdom

Weisberger M (2018) No evidence Russian engineer stabbed Antarctica colleague for spoiling book endings

Xu C, Zhu G, Xue Q, Zhang S, Du G, Xi Y, Palinkas LA (2003) Effect of the Antarctic environment on hormone levels and mood of Chinese expeditioners. Int J Circumpolar Health 62:255-267 